\title{
MEDIEVAL COURTLY LITERATURE, ROYAL PATRONAGE AND WORLD HARMONY (III)
}

"Where there is music, there is love.n

Forged from ancient Pythagorean theory, an important and ubiquitous Boethian commonplace describes how Lady Philosophy formed that writer's mores in consonance with celestial patterns and planetary movements. That is, in Neoplatonic terms, the microcosm of the individual recapitulates the macrocosm -where natural justice resides- and can be drawn upon to shape one's own character, which activity itself leads to deeper self-knowledge ${ }^{2}$.

Music conquers the demon. The medieval individual, well-tempered and in tune with the cosmos through a study of heaven's order and alternations, believed he could compose his life ultimately like a musical symphony.

Recent research by Stephen Jaeger has revealed that in the course of the Latin Middle Ages, and particularly during the proto-humanistic tenth and eleventh centuries, cosmology and astronomy became a worthy subject of study

' Sign above the piano at Nick's café, in the American film For Me and My Gal (dir. Busby Berkeley, 1942).

In an early draft, the present study formed the basis of a communication to the 5th Triennial Congress, International Courtly Literature Society, Dalfsen, The Netherlands, August, 1986. A much revised version was presented to the Medieval Academy of America meeting, University of British Colombia, Vancouver, April 1990. My thanks go to Professor Stephen Jaeget, chair of the courtly literature session, for his continued interest in and support of this research.

This study is predicated on an earlier presentation, Toward Some Definitions of Courtly Literature (1978), and relies on the inspiring book by Leo Spitzer, recommended to me over twenty years ago by Walter Ong, S.J. I am happy to acknowledge the helpful comments of Professors Carleton W. Carroll and Raymond K. Anderson. «joint».

For the deeper meaning of harmony, one is referred to the etymological Greek, harmos,

${ }^{2}$ C. Stephen JAEGER, Cathedral Schools and Humanist Learning, 583-85 (article cited hereafter as DVLG). I will also be referring often to Jaeger's book, The Origins of Courtliness: Civilizing Trends and the Formation of Courtly Ideals, 939-1210 (cited here as Origins). 
for ethical discipline. It was believed that Nature set the pattern for «man's moral development" (DVLG 583).

Jaeger has argued also that these speculative principles trickle down into vernacular literature. In courtly romance, it is the «noble hearts» (edele berzen), the sensitive, generous souls who are «...drawn together precisely by their common loathing of the life around them. They are people capable of maintaining inwardly the integrity of the emotions, the ability to loven (Jaeger, Origins 241). In the Parzifal of Wolfram, the hero's tutor, Gurnemanz, teaches a similar balance between courtliness and manliness. Those who reach this equilibrium are the "happy few», as Stendhal would later call them, who personify cosmic harmony on earth because they are in accord with Nature's wide universe. Like the doubly beautiful masterpiece that is Isold under Tristan's mentoring -she sings at once an audible song while her persona represents a lovely unheard tune (DVLG612-13) - fortunate are they who can, following this tenth-eleventh century philosophy, turn their lives into a «musical composition" or a "work of art» (ibid. 593).

Grounded on two related and entirely speculative analogies, this paper will address three main areas of concern relevant to our topic.

Analogy one: a broader argument proposes that cosmic harmony is imitated or recapitulated at the medieval court, that the equilibrium implied in the concept of world harmony reverberates -volens nolens- at the court of medieval kings, princes, and bishops.

The second analogy asserts that the concept of cosmic harmony corresponds to the social and human sphere; that, as hinted, man can shape his character by responding appropriately to the harmony of the cosmos (I am using "correspondence" in the synesthetic sense, following Spitzer's great work on Stimmung) ${ }^{3}$.

My argument -developed as a dim echo of that ideal figure, the poet Orpheus- ${ }^{4}$ will then focus on three substancial topics: first, the value-laden aims and purposes of medieval courtly literature; second, the background to the pervasive medieval notion of cosmic harmony as it appears in two significant twelfth century treatises, the Cosmographia of Bernardus Silvestris and

"LeO SPITZer, Classical and Cbristian Ideas of World Harmony: Prolegomena to an Interpretation of the Word 'Stimmung'.

4 On Orpheus, see now for example, NEWBY, A Portrait of the Artist. 
Alan of Lille's Anticlaudianus. Last of all, I will come back to the issue of world harmony insofar as it suggests a courtly fusion of the divine and the human, the cosmic and social, heavenly and earthly, macrocosm and microcosm.

I hope to demonstrate that the social context echoes the cosmic concert.

\section{II}

An important axiology of medieval courtly literature has been most recently given a strong twist in Stephen Jaeger's controversial Origins of Courtliness. He studies especially the Ottonian courtier-bishop figure and associated clerics who wrote to inspire and instruct their patrons; that is, the patrons did not directly command the poems as such; rather, the subtle argument goes, the poets themselves attempted to civilize or "tame» their patron-warriors through their writings. This concept of the "guerrier dégriffé» (or Verböflichung der Krieger-civilization of the warrior) involved the inculcation of such disciplined characteristics as elegantia morum (elegant manners), curialitas (courtliness) and mansuetudo (clemency).

As suggested, certain medieval humanistic idealists came to view life itself as a work of artistic effort: Ut per doctrinam vivere discat bomo (Let man learn through instruction how to live well). Thus, a little-known 12th-century Ciceronian-style Latin poem, the Facetus, «sets forth», urges Jaeger, "an entire plan of civilizing: education transforms life into a work of art; elegance of manners and of speech are closely related; the artistically shaped life develops forms of deportment that are close to literary forms" (Origins 166). The individual who lives with art and skill, who dresses scrupulously, cultivates proper table manners, maintains learning and life guidance, guarded speech and gesture -as well as appropriate lovemaking procedures- can be designated a vir facetus (ibid. 168). The opposite number is a slovenly rusticitas whose speech, dress and behavior are merely indifferent.

As Jaeger shows persuasively, public service and the ardors of statesmanship were deeply appreciated in the Latin Middle Ages, and most specially during the tenth and eleventh centuries, the time for the "old learning" of authority, eloquence, natural justice and personal decorum (as opposed to the new and later scholastic methodology of dispute grounded on the appeal to reason $-D V L G$ 603).

Peter of Blois' famous epistle, which borrows both from Horace and St. Paul, characterizes service to the king and republic as laudable and glorious «so long", he counsels, "as one thinks not of oneself but is all things to all men" (...sui esse immemorem, et omnium totum esse) (Origins 83-84; one wonders if this includes a Christian attitude of service and benevolence toward those in 
distress). Before Peter of Blois, Otto of Bamberg designated urbane propriety (elegantia morum) and court manners (curialitas) as the outward signs of inner virtue and dignity, so that "...the decorousness of the outer man reflects an inner harmony" (composicio) (ibid. 129).

Another mid-twelfth century treatise, a vita of a certain Bishop Wernher by Sigebot of Paulinzell, suggests a «...harmony that links inner and outer qualities: inner dignity appropriate to nobility has its counterpart in well-bred, acquired good manners; physical beauty finds its material counterpart ant the means necessary to its proper adornment in 'glorious riches'» (ibid. 131).

One of courtly literature's functions, then, was to form a civilized, self-restrained and discrete gentleman-courtier-diplomat, whose life and behavior would always harmonize politely with the environment -because of his inner nobility and outer propriety. More than just popular, he would be the great, cosmopolitan communicator. I will come back to this idea in a moment.

But on another, even higher level of thought, and providing backstage rhythms, as it were, for the courtly mode, there is one obvious mid-12th century cosmological treatise that illustrates well the concept of world harmony, namely, the Cosmograpbia by Bernardus Silvestris'. While this Chartrian philosopher gives no direct description of the harmony of the spheres as such, the notion's existence is implied again and again in the treatise. From the Megacosmos in part one that describes the creation of the universe, to part two's Microcosmos, that details the plan and fashioning of man (by Noys and Natura), cosmic harmony plays a key role.

For example, as God's creation, the universe is linked to a notion of eternity because, as Bernardus suggests, of its "continual revolution" (Wetherbee 87). The universe cannot age, is always eternally permanent, and radiate with life (ibid.). Indeed, this truth is «... the harmonious expression of [God's] mind in uniform action» (ibid.). Cosmic harmony thus manifests divine will and defeats the ravages of time and temporality, resulting in the perpetuity of the universe (89-90).

"The planetary spheres», continues Bernardus, «join in harmonious chorus» for the sun (92), now set at the center of all by Nature. Into a majestic and

'Bernardus SILVESTRIS, Cosmographia, ed. W. Wetherbee (all citations are from this text). 
delightsome musical milieu, the first man is placed. The plan of Noys is to draw man's understanding from heaven, his body from earth's elements (113). Thus man's

...mind and body, though of diverse natures, will be joined into one, such that a mysterious union will render the work harmonious. He shall be both divine and earthly, comprehend the universe about him through knowledge, and commune in worship with the gods. Thus he will be able to conform to his two natures, and remain in harmony with the dual principles of his existence (ibid.).

I can anticipate my conclusion now by arguing that the «mysterious union" of which Bernardus speaks can take place theoretically at the medieval royal or princely court -a locus where harmony should prevail to cultivate an integration of man's two natures.

Yet another, probably subsequent, twelfth-century humanistic treatise, Alan of Lille's Anticlaudianus, offers more detail on the subject of world harmony ". The allegorical figure of Concord describes the elements as bound in orderly peace and harmonious restraint. She argues convincingly that the whole universe - the panoply of stars and planets- would crash into chaos without her "covenant of harmony" (II, 242ss.; Sheridan 77).

Further, it is the music of the universe that «links the planets", whereas human music sets in order the «little cosmos", i.e., man's body, and adorns him with megacosmic beauty -a miniature world unto himself, a pygmy to the giant (III, 415ss.; Sheridan 110).

As Alan's heroine Phronesis approaches the celestial realm, she hears a novel, intoxicating song, scarcely audible; like a celestial harp, its notes breathe and sigh with subtlety (IV, 345ss.; Sheridan 130). This is the music of the spheres whose sweet and fine, powerful and magnetic music draws Phronesis, as she continues to travel across the Ether; the sound is a feast for her ears; it

... is produced by a Siren who is closely associated with the sun's movements and who by her sweet singing intimates the harp?

- Alanus de INSUliS, Anticlaudianus, ed. Bossuat; trans. J. SHERIDAN (the first citation is to the Latin text, the second to the pages of Sheridan's translation). Cf. also M. de GANDILLAC and S. ViARRE's important studies in Alain de Lille, Gautier de Châtillon...

' IV, 389ss.; Sheridan 132. Cf. Plato's Republic, 10.617ss. -the three Fates join in and sing to the Sirens' note of constant pitch. 
Alan goes on to say that once it is agreed upon, God sends down a soul to be implanted into the archetype -the Perfect or New Man, who will be virtuous and moderate, rational, tactful, wise, and pious. His soul will be joined to the flesh by Concord, who will also unite «... discordants by a stable bond" (VII, 50ss.; Sheridan 174-75). Moreover, this ideal man, as told by Honestas, will possess

....an interior life of his own which few have and an exterior life which many have, living his interior life for himself and his exterior life for the many; ... [he will] regard himself as sprung from the world, show himself all things to all men and know that in this he is wise (VII, 21 5ss.; Sheridan 180).

As St. Paul puts it so cogently (I Cor. 9.22-23): Factus sum infirmis infirmus, ut infirmos lucrifacerem. Omnibus omnia factus sum, ut omnes facerem salvos. Omnia autem facio propter Evangelium ut particeps eius efficiar ${ }^{8}$.

In the Hades known as the medieval court, such behavior was necessary for self-preservation -and not for the apostolic spread of the Holy Gospel! For example, Thomas Becket, the vir geminus, openly served the king's will but cynically managed to accomplish his own ends through cunning and intrigue (Origins 239). In such cases, hypocrisy arises because of the apparent disharmony between the inner and the outer man. But according to the ethos of the "old learning", whereby the most important quality was the golden mean of decor or decorum, such a contradiction could not exist, for «...a man must show the composition and harmony of his inner world" not by being a superficial hypocrite but by his outward bearing -once again, I woulde suggest, an ability to communicate. "Outward elegance of bearing is taken as a manifestation of compositio morum» (DVLG 596). This inward beauty and harmony should shine forth like a sunrise (DVLG 599).

I must beg the reader's indulgence and move back to a specific Old French text. It comes from the first Arthurian romance, as it has come to be known,

8 «For the weak I made myself weak. I made myself all things to all men in order to save some at any cost; and I still do this, for the sake of the gospel, to have a share in its blessings." 
composed by Chrétien de Troyes, doubtless under the patronage of the brilliant court of Champagne. The passage that follows is placed in the mouth of King Arthur:

Je sui rois, si ne doi mantir, ne vilenie consantir, ne faussete ne desmesure; reison doi garder et droiture, qu'il apartient a leal roi que il doit maintenir la loi, verite et foi et justise.

Je ne voldroie an nule guise

fere desleaute ne tor, ne plus au foible que au fort; n'est droiz que nus de moi se plaigne, et je ne voel pas que remaigne la costume ne li usages que siaut maintenir mes lignages.

De ce vos decroit il peser, se ge vos voloie alever autre costume et autres lois que ne tint mes peres li rois. L'usage Pandragon, mon pere, qui rois estoit et emperere, voel je garder et maintenir, que que il m'an doie avenir.

(Erec et Enide, vv. 1757-78) 9

As Chrétien de Troyes' royal character implies in this edifying speech, the ideal king ought to be a perfect mirror of society, a dutiful, exemplary and generous ruler, at once the protector-guarantor of renewal and innovation,

' Arthur's whole speech from CHRÉTIEN's Erec et Enide, ed. C. Carroll, is quoted here; Carroll's English translation follows: "I am the king, and I must not lie/ nor consent to any villainy/ or falsity or excess;/ I must preserve reason and rightness, / for it behooves a loyal king/ to maintain law,/ truth, faith, and justice./I should not wish in any way/ to commit disloyalty or wrong/ no more to the weak than to the strong; it is not right that any should complain of me,/ and I do not want the tradition or the custom,/ which my line is wont to uphold,/ to fall into desuetude./ It should rightly grieve you/ if I sought to impose upon you/another tradition and other laws/ than those held by my father the king./ I want to preserve and uphold/ the tradition of my father Pendragon,/ who was king and emperor,/ whatever may befall me." 
equality and equilibrium. So with the king, so with his court. Customary law here takes on the character of tradition; it is equated with Arthur's claims to legitimacy by means of his progenitor Uther Pendragon. The speech intimates the kind of reasonable, balanced and just society so often yearned for in the Middle Ages, and especially in twelfth century European courts. Indeed, it is particularly the dynamic and organic aspect of this human system, the royal or princely court, that must be stressed now -to undestand better the full and vivid array of diverse aristocratic interests and tastes, manifested, often symbolically, but nevertheless in real terms, at the court.

For at this all-too-human, Orphic crossroads, cosmic harmony -depicted so vividly by Bernardus Silvestris and Alan of Lille--can be manifested and echoed at the everyday level.

Some latent aspects of the medieval court can be inferred from the later period; at one time in 17th century France, even the Sun King's levées involved enmeshing, highly formal and mutually obligating privileges -for all individuals permitted access to them. Of the court society that surrounded Louis XIV, the eminent sociologist Norbert Elias describes a delicate, competitive, and interwoven court etiquette. Like a hieratic and ceremonial dance of life, identity comes from the existential bond linking the communal action with reciprocal behavior: «Pressure», writes the sociologist Norbert Elias of the court society that surrounded Louis XIV,

"from those of lower rank or less privilege forced the more favored to maintain their advantages, and conversely the pressure from above compelled those on whom it weighed to escape it by emulation, forcing them too into the competition for status (...). It was in etiquette, visible to all, that (an)... equilibrium was expressed. It signified for everyone yoked into it an assurance of his carefully graded social existence, though only a fragile assurance. For given the tensions by which this social system was both riddled and maintained, every link within it was incessantly exposed to attack by lower or almost equal-ranking competitions who, whether by performing services, thorough the King's favour or merely by clever tactics, sought to bring about shifts in etiquette and so in the order of rank." ${ }^{10}$

I have cited Elia's text at length because he suggests so convincingly that the delicate balance of French classical court etiquette, like a ceremonial dance of life, brought into relief not each individual but rather the opposite, i.e., the objetive became personified and each partner and his positiona relative to the others was the primary concern. As an end in itself, etiquette both distances one

11) Norbert Elias, The Court Society, 88. 
partner from another and exhibits the court society to itself. Identity comes from the existencial bond linking the communal action with reciprocal behavior.

Ironically, from such exterior tyranny over human behavior there appears to arise some kind of concert. Plutarch long ago elaborated a kind of cosmic principle, that strife and contention in public affairs stimulate virtue: "The natural philosophers are of the opinion that, if strife and discord should be banished from the universe, the heavenly bodies would stand still, and all generation and motin would cease in consequence of great harmony." "The suggestion is rich in Neoplatonic connotations, for one wonders if ever cosmic harmony might exist on this earth. But yet it may be deduced from this that what happens in heaven affects behavior and events on earth -a medieval astrological commonplace. According to Averroes, for example, the world soul's vibrations cause individual souls to vibrate, via the rays of the stars (Spitzer, World Harmony, 128).

\section{IV}

Let us return now to courtly society, where «beauty of manners» will arise (i.e., speciositas, venustas, formositas morum) when harmonious respect exists both for the social order and for other men's rights. Harmony will prevail when disorder, impulsiveness and bestial anger are stifled, when the knight's ferocitas is tempered by clementia. Peace and order will reign when the courtier and warrior are balanced together within the tactful statesman (Jaeger, Origins, 131-32, 139). Thus does Jean de Marmoutier describe, in his Angevin chronicles, the famed Geoffrey the Fair, «... the ruler who possesses warrior powers [and] shows greatness of soul... [with] no softening of his strenuitas, no sapping of warrior strength through the exercise of gentleness and clemency, but rather his strength shines so much the more brightly for being tempered with restraint" (ibid. 204).

In this way, chivalric and courtly virtues and values fuse; and the courtly individual, prince or king - by being all things to all men- assures the triumph of harmonious, integral and effective communication.

"Plutarch's Lives, 13 (Life of Agesilaus, 5.3, cited by Jaeger, 64). If one follows the newest theories of the chaologists (e.g., J. Gleick), total or predictable order in human or natural systems may in fact never be attainable. 
Borrowing the notion of "stabilized instability" from Elias, i.e., "the whole system was full of tensions... (and) sparks flew on every side" (77) -we want to urge here that "world harmony" whereby music, which for the medieval mind symbolized the "totality of the world», as Leo Spitzer shows, is a goal toward which the medieval court aspired in most of its endeavors, even if not always successfully. Thus, «government by music» (cf. Le Bourgeois Gentilhomme, I, ii: music is essential for universal peace) implies unanimous concord, an idealistic (and, of course, Platonic) goal for any human system trying to escape the Waste Land effect- total chaos and evil. Imaginary characters from Orpheus to Captain Eo personify this idealistic (and, of course, Platonic) goal. The viewpoint also reflects what might be called the Oedipus effect: when the king rules justly, the land prospers with fertility, an old theme indeed in human thought. "The king and the land are one", is how Malory phrases it. For Shakespeare, it was Antony's voice (Antony and Cleopatra) that hymned celestial harmony (cf. also Olivia's speech in Twelfth Night).

In the end, Elias describes the tensions and turbulence in a typical, many-runged, court society: «It was shot through with the countless rivalries of people trying to preserve their position by marking it off from those below while at the same time improving it by reducing the demarcation from those above» (76).

If one assumes that the typical 12 th century patron, such as, for example, Henry the Liberal of Champagne or Henry Plantagenet, sought ultimately to establish an equilibrium of moderation, etiquette and diplomacy, and to stabilize a fundamentally unstable situation in the body politic, then the analogy of Spitzer's "world harmony", the Pythagorean «music of the spheres», or the "cosmic dance», all provide a useful and striking model ${ }^{12}$. As

12 L. SPITZER, Classical and Christian Ideas of World Harmony; see the treatise De musica of ST. AUGUSTINE; cf. J. DAUPHINÉ, La Musique des éléments, 27-35 (on iconography; R. of. St. Victor and writing as music). References to this Pythagorean commonplace in the 12th century are frequent; cf., e.g., JOSEPH of EXETER, Ylias, V.1-44 (description of the musical sound of the starry firmament in motion, a celestial harmony inaudible to humans); see also, William of CONCHES, Glosae super Boetium, ed. Ch. Jourdain, 40-82; cf. T. Gregory, Anima Mundi, 80ss.; P. DrONKE, Fabula, 132 (B. Silvestris), 142 (Chaucer), 150 (Alan of Lille). MACROBIUS, Commentary on the Dream of Scipio, II, 1-4; Martianus Capella, The Marriage of Pbilology and Mercury, I, 353; II, 203-204.

See now, for appropriate background, the books by Baxter and Godwin, article by Chamberlain; cf. R. HAMmersteIn, Die Musik der Engel, 29-61; H. SCHAVERnOCH, Die Harmonie der sphären, esp. 195ss. (on the cosmic dance); R. LAMBERTON, Homer the Theologian, 37 (Pythagorean interpretations of Homer), 208, 226.

See KITTEL's Dictionary of the New Testament, II, s.v. EIPHNH (eipnvn), for the notion of Shalom, the return of all peoples from the diaspora when the whole world will come into a meaningful way of life in world harmony. 
James Miller expressed the idea laconically (5): «Human beings, vegetables, cosmic dust, we all dance to a mysterious tune, intoned in the distance by an invisible player.»

In the Purgatorio (XVI, 19-21), Dante alludes to the beauteous, heavenly choir singing in unison -Pur 'Agnus Dei' eran le loro essordia; / una parola in tutte era e un modo, / si che parea tra esse ogne concordia" (Cf. Paradiso, XIV, 118-119: "'Agnus Dei' / was sung repeatedly as their exordium, / words sung in such a way -in unison- that fullest concord seemed to be among them ${ }^{13} . "$

The union of mutual hearts and minds «... reveal(s),» writes Leo Spitzer, "only one direction of thought, or subordination to the meaning of the Whole.» One might say that the Stimmung of courtly literature reflected optimally a "concert of the stars" (World Harmony 117), whereby the patron could seek cosmic consensus and harmony. with his land and subjects. This, it was commonly believed, would lead to agricultural and human fertility, peace on earth, decorous, considerate, and civilized behavior -and, of course, completely effective human communication ${ }^{14}$.

Bringing to the medieval court setting a harmonious social context that imitated the cosmic concert meant, finally, that man could play God, just like Adam in Paradise.

\author{
RAYMOND J. CORMIER \\ Wilson College, Pennsylvania
}

For Sartre (Les Mouches III, ii), Jupiter ironically evokes planetary order and harmony -so to justify (paradoxically) the repression of freedom and the preservation of public remorse!

13 DANTE, Purgatorio. Ed., trans. A. Mandebaum.

14 P. Teilhard de Chardin (19) puts it in these words: «In truth it is impossible to keep one's gaze constantly fixed on the vast horizons opened out to us by science without feeling the stirrings of an obscure desire to see men drawn closer and closer together by an ever-increasing knowledge and sympathy until finally, in obedience to some divine attraction, there remains but one heart and one soul on the face of the earth.» 


\section{REFERENCES}

Alain de Lille, Gautier de Châtillon, Jakemart Giélée et leur temps, Colloque-Lille, 1978, Ed. H. Roussel and Fr. Suard, Lille: Presses Universitaires, 1980. (= Bien dire et bien apprendre 2).

AlaN OF LILle [AlANUS DE INSULIS], Anticlaudianus: Texte critique avec une introduction et des tables, Ed. R. Bossuat, Paris: Vrin, 1955.

-, 'Anticlaudianus' on The Good and Perfect Man, Trans. James J. Sheridan, Toronto, Pontifical Institute of Mediaeval Studies, 1973.

Augustine, De musica, Ed. G. Finaert and F.-J. Thonnard, Oeuvres de St. Augustine, Paris: Vrin, 1947, 7:430-438.

BAXTER, Charles, Harmony of the World, Columbia, Mo.: University of Missouri Press, 1984.

BernARDUS SILvestris, Cosmographia, Ed., trans. W. Wetherbee, New York: Columbia University Press 1974.

Chamberlain, David, The Music of the Spheres and the "Parlement of Foules", "Chaucer Review» 5 (1970): 32-56.

CHRÉTIEN DE TROYES, Erec et Enide, Ed., trans., Carleton W. Carroll, New York, Garland, 1987.

CORMIER, Raymond J., Toward Some Definitions of Courtly Literature, "Encomia: Bibliographical Bulletin of the International Courtly Literature Society" II, 1 (1978): 5-23 (Presidential Address).

DANTE Alighieri, Purgatorio, Ed. trans. Allen Mandelbaum, Toronto/New York: Bantam, 1984.

DAUPHINÉ, James, La Musique des éléments, motif privilégié de l' «harmonia mundi» au XIle siècle, pp. 27-35 in "Les Quatre éléments dans la culture médiévale», ed. D. Buschinger and A. Crépin, Göppingen: Kümmerle Verlag, 1983.

DRONKE, Peter, Fabula: Explorations Into the Uses of Myth in Medieval Platonism, Mitt. St. u. Texte, IX, Leiden/Cologne: Brill, 1974.

ElIAS, Norbert, The Court Society, Trans. Edmund Jephcott, New York: Pantheon, 1983.

GaNDILlaC, Maurice de, La Nature chez Alain de Lille, pp. 61-75 in "Alain de Lille, Gatuier de Châtillon»...

GleiCK, James, Chaos: The Making of a New Science, New York: Viking/Penguin, 1987.

GoDWIN, James, Harmonies of Heaven and Earth: The Spiritual Dimensiones of Music, New York: Inner Traditions, 1987.

GREGORY, Tullio, Anima Mundi: La Filosofia di Guglielmo di Conches e la scuola di Chartres, Florence: Istituto di Filosofia dell'Università di Roma, 1955. 
HAMMERSTEIN, Reinhold, Die Musik der Engel: Untersuchingen zur Musikanschauung des Mittelalters, Bern/Munich: Francke, 1962.

JAEGER, C. Stephen, Cathedral Schools and Humanist Learning, 950-1150, «Deutsche Vierteljahrsschrift für Literatur-wissenschaft und Geistesgeschichte» 61 (1987): 569-616 (= DVLG).

-, The origins of Courtliness: Civilizing Trends and the Formation of Courtly Ideals, 939-1210 (= Origins). Philadelphia: University of Pennsylvania Press, 1986.

JOSEPH OF EXETER (J. ISCANUS), Ylias or Frigia Daretis Yliados, pp. 75-211 in "J. Iscanus: Werke and Briefe», Ed. Ludwig Gompf. Leiden/Cologne: Brill, 1970.

-, The Iliad of Dares Phrigius, Trans. G. Roberts, Cape Town: Bakema, 1970.

KITTEL, Gerhard, Theological Dictionary of the New Testament, Trans. G.W. Bromiley, 10 vols., Grand Rapid, Michigan: Eerdman, 1964.

LAMBERTON, Robert, Homer The Theologian: Neoplatonist Allegorical Reading and the Growth of the Epic Tradition, Berkeley/Los Angeles: University of California Press, 1986.

MACROBIUS, Commentary on the Dream of Scipio, Trans. William Harris Stahl, New York: Columbia University Press, 1952.

MaRTianus CaPella, The Marriage of Philology and Mercury, Trans. William Harris Stahl et al, 2 vols., New York: Columbia University Press, 1971-77.

Miller, James, Measures of Wisdom: The Cosmic Dance in Classical and Christian Antiquity, Toronto: University of Toronto Press, 1986.

NEWBY, Elizabeth A., A Portrait of the Artist: The Legends of Orpheus and Their Use in Medieval and Renaissance Aesthetics, New York: Garland, 1990.

Plutarch's Lives (Life of Agesilaus), Trans. Perrin, Bernadette, London/New York: Heineman-Putnam's, 1917.

SARTRE, J.-P., Les Mouches, Paris: Gallimard, 1949.

SCHAVERNOCH, Hans, Die Harmonie der Sphären: Die Geschichte der Idee des Welteneinklangs und der Seeleneinstimmung, Freisburg/Munich: K. Alber, 1981.

SPITZER, Leo, Classical and Christian Ideas of World Harmony: Prolegomena to an Interpretation of the Word "Stimmung". Baltimore: Johns Hopkins University Press, 1963.

TeilhaRd DE ChaRdin, Pierre, Hymn of the Universe, trans. G. Vann, New York: Harper \& Row, 1969.

VIARRE, Simone, La Description du palais de la nature dans "Anticlaudianus" d'Alain de Lille (I, 55-206), pp. 153-69 in "Alain de Lille, Gautier de Châtillon»...

WILliam OF CONCHES, Glosae super Boetium, Ed. Ch. Jourdain, «Notices et extraits des manuscrits de la Bibliothèque Impériale» XX, 2 (1862): 40-82.

\section{RÉSUMÉ}

La musique vainc le diable, comme doit avoir dit Pythagore. Cette étude aborde le problème, pour la troisième fois déjà et à nouveau sur les traces de Stephen Jaeger, 
qui a défendu à ce propos aussi la thèse que bon nombre de ces principes spéculatifs tombaient dans la littérature vernaculaire. On suggère que l'harmonie cosmique est réunie à la Cour médiévale, telle que la Table Ronde d'Arthur, et que l'équilibre sous-entendu dans le concept de l'harmonie du monde se reflète. volens nolens, à la cour des rois médiévaux, princes et évèques (Jaeger, Origins of Courtliness). Une seconde analogie soutient que le concept $\mathrm{d}$ 'harmonie cosmique correspond à la sphère sociale et humaine; comme le préconise Boethius, les humains peuvent aiguiser leur caractère en répondant convenablement à l'harmonie cosmique, conduisant ainsi à une connaissance personnelle plus profonde. Trois thèmes sont discutés: a) les buts de l'échelle de valeur de la littérature médiévale raffinée; b) l'arrière plan de la notion d'harmonie cosmique -que l'on retrouve dans la description de la Perfection, ou Homme Nouveau, une «union mystérieuse»- et qui est décrite dans deụx traités importants du douzième siècle, la Cosmographia de Bernardus Silvestris et l'Anticlaudianus de Alan of Lille. La dernière préoccupation est le but de l'harmonie du monde étant donné qu'elle suggère une fusion raffinée du divin et de l'humain, du cosmic et du social, du terrestre et du céleste, du macrocosme et du microcosme.

\section{SUMMARY}

Music conquers the demon, as Pythagoras might have said. The present study approaches the problem yet a third time, and once again in the footsteps of Stephen Jaeger, who has argued cogently also that many of these speculative principles trickle down into vernacular literature. It is proposed that cosmic harmony is recapitulated at the medieval court, such as at Arthur's Round Table, and that the equilibrium implied in the concept of world harmony reverberates -volens nolens- at the court of medieval kings, princes and bishops (Jaeger, Origins of Courtliness). A second analogy asserts that the concept of cosmic harmony corresponds to the social and human sphere; that, as Boethius urged, humans can shape their character by responding appropriately to cosmic harmony, thus leading to deeper selfknowledge. Three topics are discussed: a) the value-laden aims of medieval courtly literature; b) the background to the notion of cosmic harmony -seen in the description of the Perfect, or New Man, a «mysterious union»- and described in two significant twelfth century treatises, the Cosmographia of Bernardus Silvestris and Alan of Lille's Anticlaudianus. The last concern is the issue of world harmony insofar as it suggests a courtly fusion of the divine and the human, the cosmic and social, heavenly and earthly, macrocosm and microcosm. 